\title{
The invasive harvestman Opilio canestrinii (Thorell, 1876) (Opiliones: Phalangiidae) in Poland
}

\author{
Robert ROZWALKA* and Wojciech STARĘG*** \\ *Department of Zoology, Maria Curie-Sklodowska University, Akademicka 19, 20-033 Lublin; \\ e-mail: arachnologia@wp.pl, \\ ** Institute of Biology, Siedlce University of Natural Sciences and Humanities, Prusa 12, 08-110 Siedlce; \\ e-mail:wojstar@vp.pl
}

\begin{abstract}
Opilio canestrinit is an expansive harvestman originating from the Apennine Peninsula which in the last decades of the XX century invaded Central Europe. New details on the occurrence of the species in Poland are given. The investigation carried out in Lublin revealed that currently this species is one of the most common harvestmen in Polish urban areas. The new data suggest that the species occurs in the whole country but its distribution is limited mainly to large and mid-sized towns.
\end{abstract}

Key words: Opilio canestrinit, synanthropic fauna, competition, invasive harvestman, Poland

\section{INTRODUCTION}

The original range of Opilio canestrinii (Thorell, 1876) comprises Tunisia, the Apeninne Peninsula together with the neighboring islands (Sicily, Malta, Elba) and parts of southern Alps (Martens 1978, Gruber 1985, 1988, Komposch 1993, Delfosse 2004). It is probably known also from Algeria (Gruber 1988) but the old data need verification. During the second half of the XX century the species began to invade northwards, first to Austria (found in Innsbruck already in 1968 and in Wien 1980; Gruber 1985, Komposch \& Gruber 2004, Komposch 2011), then to Germany (Mainz, Stuttgart, Berlin; Martens 1978) and Switzerland (Luzern; Martens 1978). This process could be very well demonstrated by its distribution in Germany: Martens (1978) mentioned only three localities, Gruber (1985) already 12, and now (Bliss 1990, Staudt 2010 ) the species is known from 169 localities. Nearly in the same time $O$. canestrinii has been found in Denmark (Enghoff 1987, Gruber 1988), southern Sweden (Enghoff 1988), Belgium (Vanhercke 1998), the Netherlands (Van der Weele 1993), Slovenia (Novak et al. 2002), Czech Republic (Klimeš 1995, Klimeš \& Roušar 1998), Slovakia (Klimeš 1999, Mašán \& Mihál 2007), Hungary (Lengyel 2010), France (Delfosse \& Iorio 2009, Iorio \& Delfosse 2010) and southern England (Hillyard 2000, 2005). Partial summary on the invasion is included in the paper by Blick \& Komposch paper (2004).

Some information on $O$. canestrinii in Poland can be found in paper of Staregga (2004). The species has been noted from three localities only: Warszawa-Kamionek [UTM EC 08], Warszawa-Jelonki [DC 98] and Białystok-Śródmieście [FD 48] (Fig. 1). The first specimens were observed in Warsaw in 1979 and 1980 and collected in 1982. The very scarce number of localities and specimens suggested that the species was very rare in the country. This view has been revised in this article. The results of several years of the research on opilionid fauna in Poland were used to review the occurrence of $O$. canestrinii. Some new data allowed to supplement the information on this subject. 


\section{METHODS OF STUDY}

The material has been collected by hand (no other method could be used on walls, fences etc.). Pitfall traps were successfully used only in the Kępa Redlowska Reserve. The collected material was identified mainly by the first author and it is stored in his collection in Lublin. Several earlier series were identified by the second author and stored in his reference collection in Warsaw.

\section{LIST OF LOCALITIES}

All Polish localities of Opilio canestrinii are in the lowlands (Fig. 1), from about $20-30 \mathrm{~m}$ a.s.1. (Moczyly, Sieraków) in the north of the country to 250-280 $\mathrm{m}$ a.s.1. (Sosnowiec, Tomaszów Lubelski) in the south. In parentheses are data already published (Staręga 2004).

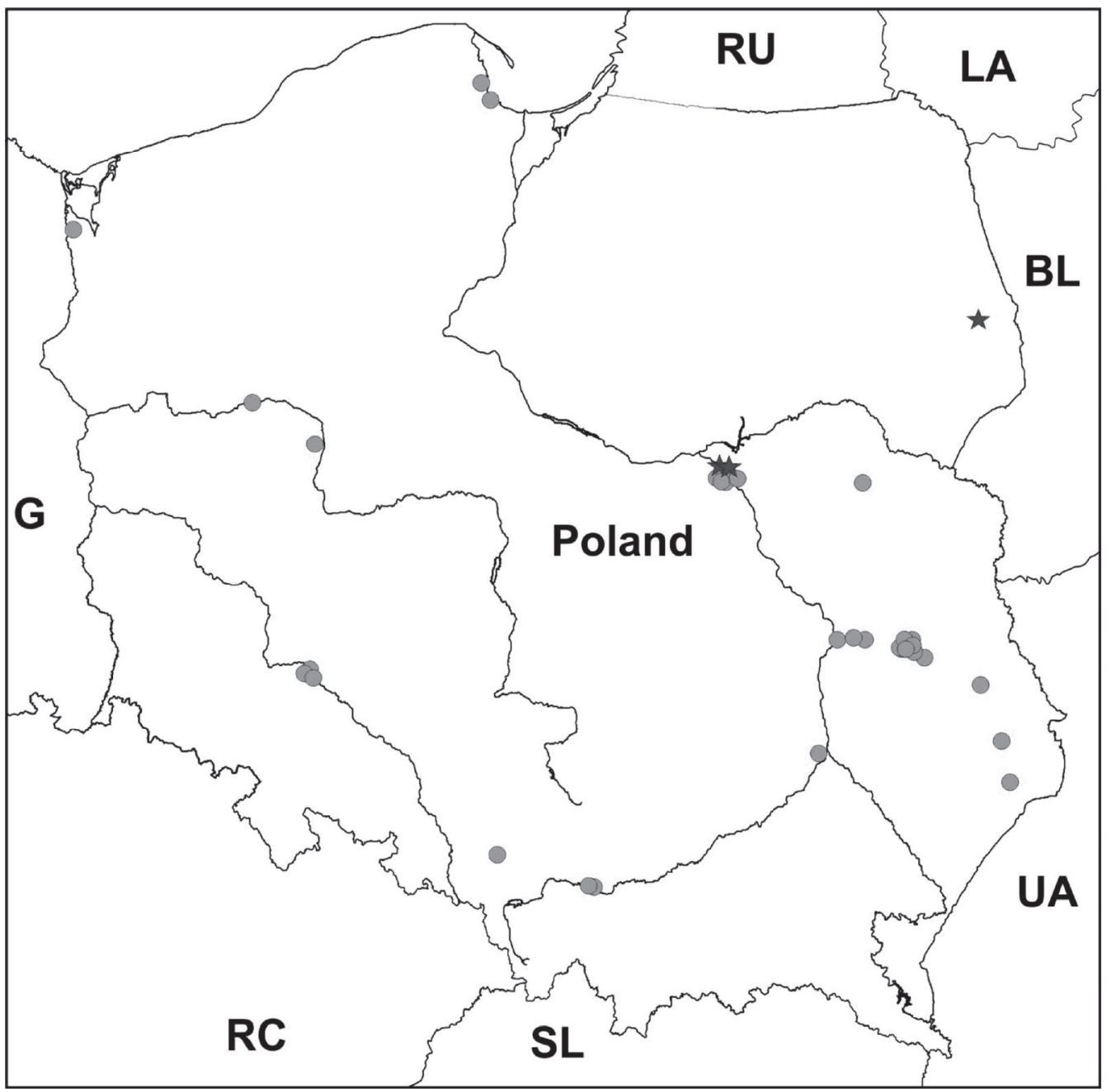

Fig. 1. Distribution of Opilio canestrinii in Poland: stars indicate the publihed data, dots - the new localities. 
Gdynia-Redlowo [CF 44; 54 $29^{\prime} \mathrm{N}, 18^{\circ} 33^{\prime} \mathrm{E}$ ], Kepa Redlowska forest reserve, beech wood,

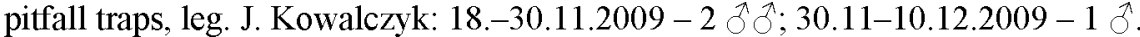

Gdańsk-Wrzeszcz [CF $\left.42 ; 54^{\circ} 22^{\prime} \mathrm{N}, 18^{\circ} 35^{\prime} \mathrm{E}\right]$, garden vegetation, 28.09 .2005 phot. doc. M. Wierzbicki- 1 \%.

Moczyly [VV 60; 53 $\left.{ }^{\circ} 19^{\prime} \mathrm{N}, 14^{\circ} 27^{\prime} \mathrm{E}\right]$, distr. Police, in garden bower, $09.2010 \mathrm{leg}$. A. SzlauerŁukaszewska-1 1 .

(Bialystok-Śródmieście [FD 48; 530ㅗ $08^{\prime} \mathrm{N}, 2^{\circ} 09^{\prime} \mathrm{E}$ ], Zamenhofa Str., walls of building, leg. W. Staręga: 23.10.1994 - 1 q and obervations of numerous specimens in summer and autumn months 1995-1998 on outer walls, on the balcony overgrown by hop and Virginia creeper (2. floor) and even in the flat).

Sieraków [WU 73; 52 $38^{\prime} \mathrm{N}, 16^{\circ} 03^{\prime} \mathrm{E}$ ], distr. Międzychód, filling station, 23.08.2011 leg. A. Zawal - $1 \hat{\jmath}$.

Poznań-Ogrody [XU 20;52 $55^{\prime} \mathrm{N}, 16^{\circ} 53^{\prime} \mathrm{E}$, Dąbrowskiego Str. 159, walls of buildings, 20.08.-23.09.2010 leg. P. Sienkiewicz-3 $\partial \hat{\partial}, 1$ \%.

Łomianki [DC 99; $\left.52^{\circ} 20^{\prime} \mathrm{N}, 20^{\circ} 53^{\prime} \mathrm{E}\right]$, shrubs in the garden, 3.10.1986 W. Staręga - 1 o, 1 \%; 28.08.2005 phot. doc. L. Grüm -1 q.

(Warszawa-Jelonki [DC 98; 52 $13^{\prime} \mathrm{N}, 2^{\circ} 54^{\prime} \mathrm{E}$ ], wooden fence, 20.09.1985 leg. W. Jędryczkowski - $1 \hat{\jmath}$ ).

Warszawa-Ujazdów [EC $\left.08 ; 52^{\circ} 13^{\prime} \mathrm{N}, 21^{\circ} 01^{\prime} \mathrm{E}\right]$, Botanical Garden of the Warsaw University, 26.09.2010 leg. R. Rozwałka $-2 \hat{\jmath}, 1$ \%.

Warszawa-Łazienki [EC 08; $52^{\circ} 12^{\prime} \mathrm{N}, 21^{\circ} 02^{\prime} \mathrm{E}$ ], park, tree trunks, 3.07.2007 phot. doc. D. Majgier - 1 juv.

Warszawa-Kamionek [EC $08 ; 52^{\circ} 14^{\prime} \mathrm{N}, 21^{\circ} 04^{\prime} \mathrm{E}$ ], walls of buildings, mostly by night, leg. et obs. W. Starega: 17.09.1979- 1 ; $21.09 .1980-1$ \% 1 ; ; $(7.09 .1982-1$; $9.08 .1986-1$

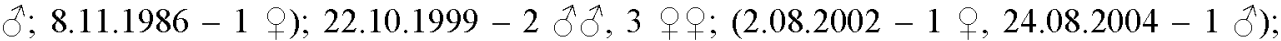
27.09.2010-1 $9 ; 15.11 .2010-1 \hat{\partial}$.

Warszawa-Wawer [EC 18; $52^{\circ} 10^{\prime} \mathrm{N}, 21^{\circ} 08^{\prime} \mathrm{E}$ ], near to Vistula, 22.07.2007 phot. doc. D. Majgier $-1 \%$.

Siedlce-Osiedle Warszawskie [EC 88; 52 $09^{\prime}$ N, $22^{\circ} 14^{\prime}$ E], Romanówka Str., insolated wall of building, 07.2008 leg. M. Stańska -1 .

Kazimierz Dolny [EB 68; $51^{\circ} 19^{\prime} \mathrm{N}, 21^{\circ} 56^{\prime} \mathrm{E}$ ], walls of buildings around the old Market Place (Rynek), 19.07.2009 leg. R. Rozwalka -20 (several further specimens observed).

Wawolnica [EB 78; $51^{\circ} 17^{\prime} \mathrm{N}, 22^{\circ} 08^{\prime} \mathrm{E}$ ], distr. Pulawy, outer walls of the church, 19.07.2009 leg. R. Rozwalka $-1 \%$.

Nałęczów [EB 88; $51^{\circ} 17^{\prime} \mathrm{N}, 22^{\circ} 12^{\prime}$ E], fence of sanatorium park, 19.07.2009 leg. R. Rozwalka -1 .

Lublin-Dębówka [FB 08; $51^{\circ} 16^{\prime} \mathrm{N}, 22^{\circ} 28^{\prime} \mathrm{E}$ ], -Slawin [FB $08 ; 51^{\circ} 15^{\prime} \mathrm{N}, 22^{\circ} 30^{\prime} \mathrm{E}$ ], -CzechówPoludnie [FB 08; $51^{\circ} 15^{\prime} \mathrm{N}, 22^{\circ} 32^{\prime} \mathrm{E}$ ], -Ponikwoda [FB $18 ; 51^{\circ} 15^{\prime} \mathrm{N}, 22^{\circ} 35^{\prime} \mathrm{E}$ ], -Wieniawa [FB 07; 51 ${ }^{\circ} 14^{\prime} \mathrm{N}, 22^{\circ} 31^{\prime} \mathrm{E}$ ], -Śródmieście [FB 07; 51 ${ }^{\circ} 14^{\prime} \mathrm{N}, 22^{\circ} 32^{\prime} \mathrm{E}$ ], -Stare Miasto [FB $07 ; 51^{\circ} 15^{\prime} \mathrm{N}, 22^{\circ} 34^{\prime} \mathrm{E}$ ], -Kalinowszczyzna [FB 07; 51 ${ }^{\circ} 15^{\prime} \mathrm{N}, 22^{\circ} 34^{\prime} \mathrm{E}$ ], -Konstantynów [FB 07; $51^{\circ} 14^{\prime} \mathrm{N}, 22^{\circ} 30^{\prime} \mathrm{E}$ ], -Rury [FB 07; $51^{\circ} 14^{\prime} \mathrm{N}, 22^{\circ} 31^{\prime} \mathrm{E}$ ], -Czuby Pólnocne [FB 07; $51^{\circ} 14^{\prime} \mathrm{N}, 22^{\circ} 29^{\prime} \mathrm{E}$, -Czuby Poludniowe [FB 07; 51 ${ }^{\circ} 13^{\prime} \mathrm{N}, 22^{\circ} 31^{\prime} \mathrm{E}$ ], -Tatary [FB 17; $51^{\circ} 14^{\prime} \mathrm{N}, 22^{\circ} 35^{\prime} \mathrm{E}$ ], -Bronowice [FB 17; $51^{\circ} 13^{\prime} \mathrm{N}, 22^{\circ} 35^{\prime} \mathrm{E}$ ], -Dziesiata [FB 17; $51^{\circ} 13^{\prime} \mathrm{N}$, $22^{\circ} 34^{\prime} \mathrm{E}$ ], -Zadebie [FB 17; $51^{\circ} 15^{\prime} \mathrm{N}, 22^{\circ} 36^{\prime} \mathrm{E}$ ], -Felin [FB 17; $51^{\circ} 13^{\prime} \mathrm{N}, 22^{\circ} 37^{\prime} \mathrm{E}$ ] altogether collected in the period 2004-2010 (leg. R. Rozwalka) - 381 $\hat{\jmath}, 359$ 우, 107 juv. and many more specimens observed. The species is very common in Lublin, over 100 localities have been documented. Their detailed mentioning would be unnecessary increasing of the volume of the present paper. Therefore only the quarters were given. The 
very first specimens have been found in the city on $21.09 .2004(1), 2$ 우 - leg. $\mathrm{R}$. Rozwalka, det. W. Staręga).

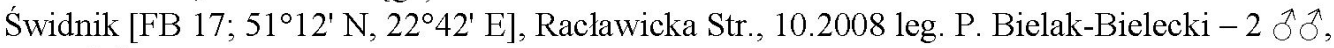
3 우.

Świdnik [FB 17; 51 ${ }^{\circ} 13^{\prime} \mathrm{N}, 22^{\circ} 42^{\prime} \mathrm{E}$ ], Kosynierów Str., brick fence, 09.2009 leg. R. Rozwałka $-1 \hat{\jmath}$.

Wroclaw-Gądów Maly [XS 36; 51 $07^{\prime} \mathrm{N}, 16^{\circ} 57^{\prime} \mathrm{E}$ ], outer walls of buildings, 25.08.2009 leg.

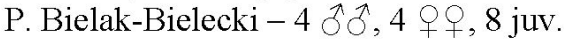

Wroclaw-Stare Miasto [XS 46;51 $06^{\prime} \mathrm{N}, 17^{\circ} 01^{\prime} \mathrm{E}$ ], walls of buildings and brick fences in the vicinity of the former Świebodzki railway station, 4.-5.10.2009 leg. P. Bielak-Bielecki-11 $\hat{\partial}, 15$ 우, 1 juv.

Wroclaw-Dąbie [XS 46;51 $06^{\prime} \mathrm{N}, 17^{\circ} 04^{\prime} \mathrm{E}$ ], walls of buildings and brick fence in Zoological Garden, 11.10.2009 leg. P. Bielak-Bielecki-12 $\partial \delta, 8$ 우.

Krasnystaw [FB 55; 50 59' N, $\left.23^{\circ} 10^{\prime} \mathrm{E}\right]$, Kościuszki Str., brick fences and walls of buildings, 23.08.2009 leg. R. Rozwałka -2 우 (several more specimens observed).

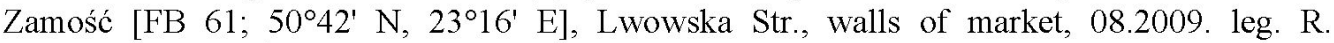
Rozwalka -13 .

Sandomierz-Stare Miasto [EB 51; 50 40' N, 21 ${ }^{\circ} 44^{\prime}$ E], walls of buildings, 13.09 .2009 leg. R. Rozwalka $-4 \hat{\delta} \hat{\delta}, 2$ 우우 (several further specimens observed).

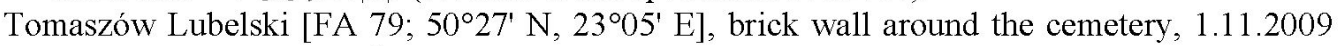
obs. R. Rozwalka $-1 \hat{\jmath}$.

Sosnowiec-Dańdówka [CA 67; 50 $17^{\prime} \mathrm{N}, 19^{\circ} 09^{\prime}$ E], allotments, 28.05 .2007 phot. doc. D. Majgier -1 juv.

Kraków-Ogród Botaniczny (Botanical Garden) [DA 24; 50 03' N, 1957' E], walls of buildings, by night, 3.-4.08.2007 leg. R. Rozwalka - $1 \hat{\jmath}, 2$ 우우.

Kraków-Dąbie [DA 24; 50 $03^{\prime} \mathrm{N}, 19^{\circ} 59^{\prime} \mathrm{E}$ ], by the mouth of Praqdnik into Vistula, tree stems, 12.10.2009 phot. doc. J. Radwański - 1 juv. (many more further specimens observed).

\section{PHENOLOGY}

Opilio canestrinii is a summer-autumnal species (Martens 1978). The juveniles, already identifiable (Fig.3), appear in about middle of May and occur regularly to the middle of August and sporadically even much later (Fig. 2). Males (Fig. 4) appear in the first decade of July and live to end of November-early December (Fig. 3). Females (Fig. 5) - from the middle of July nearly to middle of December (Fig. 2). Active specimens of $O$. canestrinii were collected even after transitory ground frosts or snow-falls. Copulation has been observed several times (Fig. 2).

\section{females}

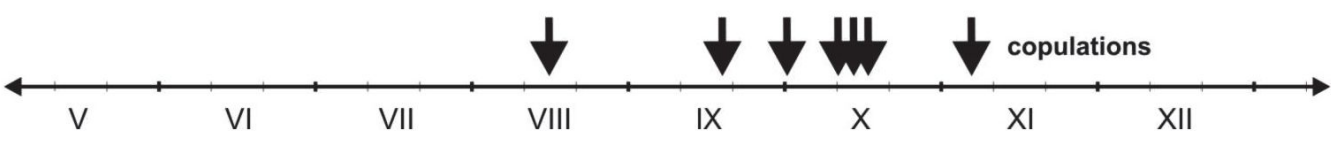

Fig. 2. Phenology of Opilio canestrinit on summaric observation in years $2008-2009$ in Lublin 

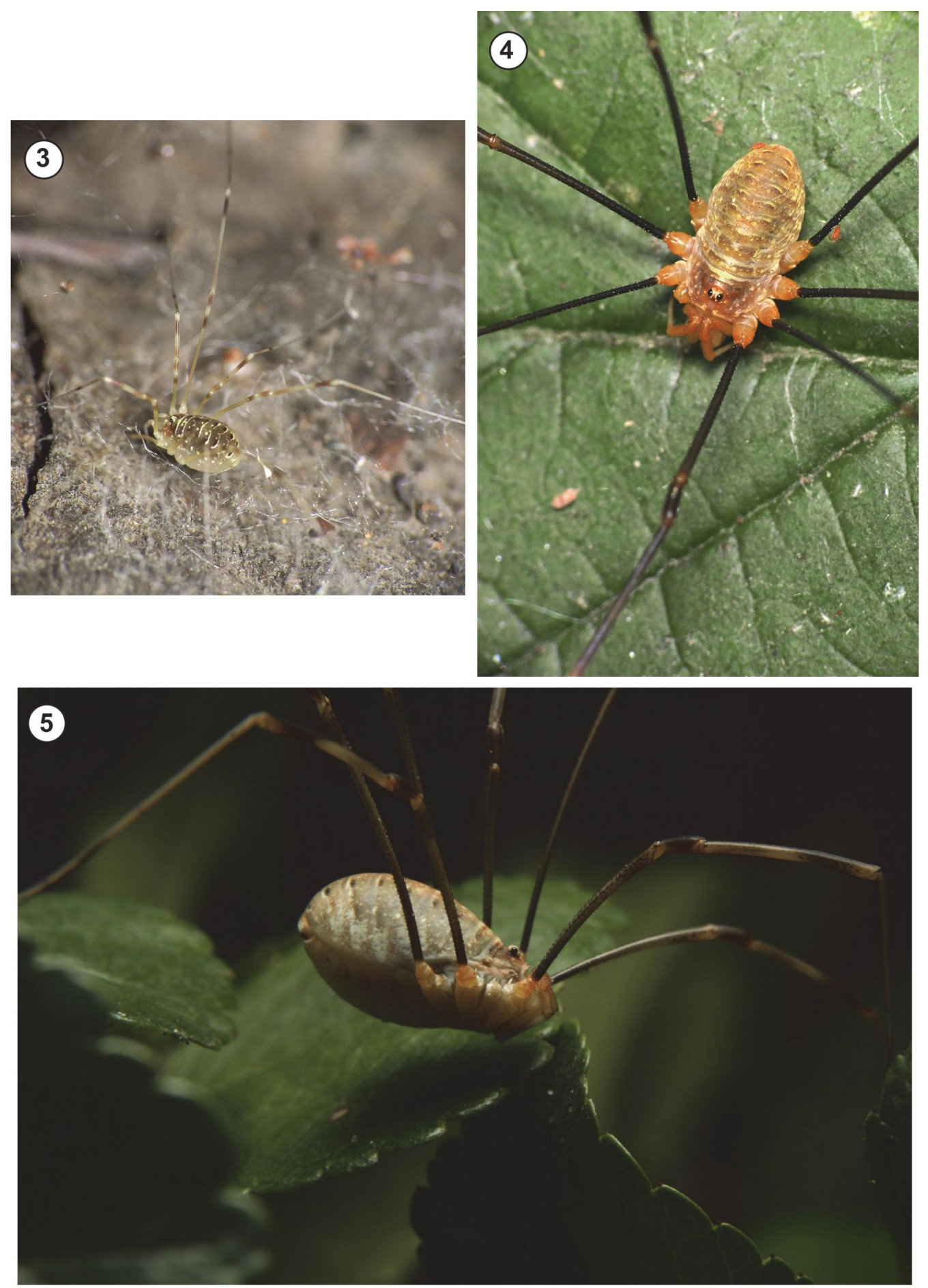

Figs 3-5. Opilio canestrinit: 3 - juvenile (phot. D. Majgier), 4 - male (phot. D. Majgier), 5 - female (phot. M. Wierzbicki), 


\section{RESULTS AND DISCUSSION}

Opilio canestrinii is a very common species in Lublin which can be regularly found throghout the city. It is very numerous on the outer walls of buildings and fences, independently from the basis (brick, concrete, stone, wood). Sporadically, it comes even into staircases and flats. It can be confirmed also in Bialystok (W. Starega's observations). Moreover it occurs on loess walls of escarpments and gullies (or excavations) within the city. The species is equally common on tree and bush trunks in city parks and afforested squares (Tab. 1) and even in allotments. It lives also on the ground: on lawns, flower-beds and so on. The comparative search of natural biotopes in the vicinity of Lublin did not reveal the species. Similar situation was in other natural localities in South-Eastern Poland (e.g. Rozwałka 2009 and unpubl. data). The data from the Netherlands or Germany, where this expansive species occurs in natural habitats (Wijnhoven et al. 2007, Wijnhoven 2009) or from Austria where it encroaches to agricultural land and exceptionally to forests (Komposch \& Gruber 2004). The new data show that the species may also occur in natural biotopes in Poland (the Kępa Redlowska Nature Reserve).

Table 1. Example data on the numbers of $O$. canestrinit in chosen localities in Lublin. Material has been collected by night, on sight, looking for and catching all harvestmen visible in the light of strong electrical lamp in zone from about the ground up to $2.2-2.3 \mathrm{~m}$ during about two hours.

\begin{tabular}{|c|c|c|c|c|c|c|}
\hline \multirow[t]{2}{*}{ Species } & \multicolumn{3}{|c|}{$\begin{array}{c}\text { Lublin Castle, outer walls and brick- } \\
\text { metal fence }\end{array}$} & \multicolumn{3}{|c|}{ Saxon Garden (Ogród Saski), tree trunks } \\
\hline & 1.10 .2008 & 5.10 .2008 & 10.10 .2008 & 2.10 .2008 & 6.10 .2008 & 10.10 .2008 \\
\hline $\begin{array}{l}\text { Trogulus tricarinatus } \\
\text { (Linnaeus, 1761)-compl. }\end{array}$ & 399 & 11 우 & $79+$ & 19 & & \\
\hline $\begin{array}{l}\text { Mitostoma chrysomelas } \\
\text { (Hermann, 1804) }\end{array}$ & & & & & & $1 \delta^{\pi}$ \\
\hline $\begin{array}{l}\text { Nemastoma lugubre (O.F. } \\
\text { Müller, 1776) }\end{array}$ & & 18 & & & 1 우 & \\
\hline $\begin{array}{l}\text { Leiobunum rotundum } \\
\text { (Latreille, 1798) }\end{array}$ & $\begin{array}{l}17 \hat{\delta} \delta \\
17 \text { 우오 }\end{array}$ & $\begin{array}{l}10 \text { 주, } \\
12 \text { 우우 }\end{array}$ & $\begin{array}{l}16 \delta^{\pi} \delta^{-2} \\
19 \text { 우우 }\end{array}$ & $\begin{array}{l}19 \pi \delta^{\pi} \\
5 \text { 우우 }\end{array}$ & $\begin{array}{l}21 \text { ॠठ, } \\
15 \text { 우, } 1 \mathrm{j}\end{array}$ & $\begin{array}{l}11 \delta^{\pi} \sigma^{\pi} \\
12 \text { 오우 }\end{array}$ \\
\hline $\begin{array}{l}\text { Lacinius ephippiatus (C.L. } \\
\text { Koch, } 1835 \text { ) }\end{array}$ & & 1 क & & & $1 \delta^{n}$ & \\
\hline $\begin{array}{l}\text { Oligolophus tridens (C.L. } \\
\text { Koch, 1836) }\end{array}$ & 1 ㅇ & 10 & & $\begin{array}{l}6 ठ \delta, 1 \text { क } \\
2 \mathrm{j}\end{array}$ & $\begin{array}{l}12 \delta \delta \\
10 \text { 우, } 5 \mathrm{j}\end{array}$ & $\begin{array}{l}8 \hat{0}, \\
709,2 \mathrm{j}\end{array}$ \\
\hline $\begin{array}{l}\text { Phalangium opilio Linnaeus, } \\
1758\end{array}$ & $\begin{array}{l}7 \hat{O \delta}, \\
19,2 \mathrm{j} \\
\end{array}$ & $\begin{array}{l}11 \delta 0 \\
590,4 \mathrm{j}\end{array}$ & $\begin{array}{l}4 \delta^{\pi}, \\
690,1 j \\
\end{array}$ & $\begin{array}{l}10 \hat{\jmath}, \\
1599,4 j\end{array}$ & $\begin{array}{l}60^{x} 0^{-3} \\
1290 \\
\end{array}$ & $\begin{array}{l}90 \hat{0}, \\
890,7 \mathrm{j}\end{array}$ \\
\hline $\begin{array}{l}\text { Rilaena triangularis (Herbst, } \\
\text { 1799) }\end{array}$ & & & & $1 \mathrm{j}$ & & $1 \mathbf{j}$ \\
\hline Lophopilio palpinalis & & 18 & 1 오 & & 10 & \\
\hline $\begin{array}{l}\text { Opilio canestrinit (Thorell, } \\
\text { 1876) }\end{array}$ & $\begin{array}{l}24 \delta^{\lambda}, \\
1399,2 j\end{array}$ & $\begin{array}{l}53 \text { ठ̊ } \\
15 \text { 오 }\end{array}$ & $\begin{array}{l}45 \delta^{\pi / 2}, \\
19 \text { 오 }\end{array}$ & $\begin{array}{l}22 \delta^{\pi}, \\
8 \text { 오 }\end{array}$ & $\begin{array}{l}32 \text { o } 0 \\
18 \text { 옹 }\end{array}$ & $\begin{array}{l}25 \delta^{-\pi}, \\
2990,2 \mathrm{j}\end{array}$ \\
\hline $\begin{array}{l}\text { Opilio parietinus (De Geer, } \\
1778 \text { ) }\end{array}$ & 18 & & 1 우 & & & \\
\hline $\begin{array}{l}\text { Opilio saxatilis C.L. Koch, } \\
1839\end{array}$ & $\begin{array}{l}260 \hat{0}, \\
709,3 \mathrm{j}\end{array}$ & $\begin{array}{l}37 \text { ठf, } \\
18 \text { 웅, } 12 \mathrm{j}\end{array}$ & $\begin{array}{l}41 \text { की } \\
31 \text { की, } 22 \mathrm{j}\end{array}$ & 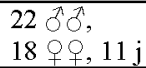 & $\begin{array}{l}24 \delta \delta, \\
31 \text { \&ᄋ, } 6 \mathrm{j}\end{array}$ & $\begin{array}{l}31 \text { ofं, } \\
41 \text { oी, } 19 \mathrm{j}\end{array}$ \\
\hline $\begin{array}{r}\text { Percentage of } O . \text { canestrinit } \\
\text { in samples }\end{array}$ & $32,2 \%$ & $35,4 \%$ & $30,0 \%$ & $20,7 \%$ & $23,1 \%$ & $25,1 \%$ \\
\hline Total percentage & & $32,5 \%$ & & & $23,3 \%$ & \\
\hline
\end{tabular}

The results of several years observations made in Lublin by the first author point out that $O$. canestrinii belongs to the most common harvestmen in strongly urbanized areas. The qualitative investigations on walls of buildings showed that $O$. canestrinii took meanly $32,5 \%$ harvestmen caught, and the data for tree trunks in a city park were not much lower $-23,3 \%$ (Tab. 1). Such numerous occurrence of the „newcomer” could not be without meaning on the composition of the "native synanthropic fauna”. First of all, Opilio parietinus, a typical 
synanthropic species decreased considerably in number. Comparative data from Warsaw and vicinity (Starega 1963) show that in the past $O$. parietinus was one the most common synanthropes in the urban areas. Now, in Lublin $O$. parietinus belongs to very rare species (Tab. 1), and its place has been taken over by $O$. canestrinii. Similar situation takes place in Warsaw - O. parietinus became extremely rare (W. Starega, unpubl. data). During field work it was several times observed as $O$. canestrinii hunted (eaten) specimens of Opilio saxatilis and Leiobunum rotundum. It confirms that the immediate predation can, besides the habitat and food competition, cause the damage among the species previously living in synanthropic biotopes. Observations in rural areas, where $O$. canestrinii was not yet found, show that $O$. parietinus is still quite common. The findings of $O$. canestrinii in some other Polish cities (Kraków, Poznań, Warszawa, Wroclaw) as well as single samples and observations in other localities give evidence that $O$. canestrinii begins to colonize the whole country, may-be for the time being without towns in the mountains (Fig. 2). Very similar situation has been observed also in Austria, where O. parietinus is surrendering in urban areas (Komposch 2002).

Starega (2004) identified the first specimen of $O$. canestrinii in Warsaw already in 1982 (in fact the very first ones were observed in 1979 and 1980 but got lost). Very few localities and scarce samples ( $1-2$ specimens) could show that the species is in Poland very rare and rather accidental than well established. The situation has diametrally changed within last $10-15$ years. Already by the end of 90-ties the species has been observed in dozens of specimens in a single house end even balcony in Białystok. But the real explosion took place in 2004 in Lublin: several years of investigation (2004-2010) revealed that the species is now one of dominants in the city area (over 1000 specimens collected and observed). The results of field investigations show that its occurrence is limited mainly to large or mid-sized towns, whereas in smaller settlements it is very rare or absent. In South-Eastern Poland O. canestrinii has not been found in the natural biotopes but the information from the Kępa Redlowska reserve point out that it may be only the matter of time. The control of the invasion is required, because in natural habitats it may exert pressure on other native species, for example the rare Opilio dinaricus Šilhavý, which occurs in the same habitat and exhibits similar phenology.

\section{ACKNOWLEDGEMENTS}

The authors wish to thank the following persons: M.Sc. P. Bielak-Bielecki, M.Sc. J. Kowalczyk, M.Sc. J.M. Radwański, Ph.D. P. Sienkiewicz, Ph.D. M. Stańska, Ph.D. A. SzlauerŁukaszewska and D.Sc. A. Zawal - for the information and material of Opilio canestrinii. Special thanks are due to Prof. L. Grüm, D. Majgier and M. Wierzbicki - for agreement to publish their photographic material, which enriched the present publication. Ph.D. Ch. Komposch (Graz, Austria) deserves of our exceptional gratitude for his critical comments and some additions to literature.

\section{REFERENCES}

BLICK T., KOMPOSCH Ch. 2004. Checkliste der Weberknechte Mittel- und Nordeuropas. Checklist of the harvestmen of Central and Northern Europe (Arachnida: Opiliones). Version 27. Dezember 2004. Internet: http://www. AraGes.de/checklist.html\#2004_Opiliones

BLISS P. 1990. Zur Verbreitung von Opilio canestrinii (Thorell) in der Deutschen Demokratischen Republik (Arachnida: Opiliones, Phalangiidae). Acta Zoologica Fennica 190: 41-44.

DELFossE E. 2004. Catalogue préliminaire des Opilions de France métropolitaine (Arachnida, Opiliones). Bulletin de Phyllie 20: 34-58.

DELFOSSE E., IORIO E. 2009. Contribution à la connaissance des Opilions de France métropolitaine (Arachnida: Opiliones). I. Bulletin de la Société Linnéenne de Bordeaux 144 (N.S.) 37: 99-106.

ENGHOFF H. 1987. Opilio canestrinii (Thorell, 1876) - en nyinnvandret mejer i Danmark (Opiliones). Entomologiske Meddelelser 55: 39-42. 
ENGHOFF H. 1988. Operation Opilio 1987 - en undersøgelse af mejere på mure, stakitter o. 1. steder i Danmark. Entomologiske Meddelelser 56: 65-72.

GRUBER J. 1985. Über Opilio canestrinii (Thorell) und Opilio transversalis Roewer (Arachnida: Opiliones, Phalangiidae). Annalen Naturhistorisches Museums Wien 86(B): 251-273.

GRUBER J. 1988. Neunachweise und Ergänzungen zur Verbreitung von Opilio canestrinii (Thorell) und Opilio transversalis Roewer. Annalen Naturhistorisches Museums Wien 90(B): 361-365.

HLLyARD P. D. 2000. Opilio canestrinii (Thorell, 1876) - new species record for Britain. Ocularium 3. Internet: http:/www.britishspiders.org.uk/srs/ors03.html

HILLYARD P. D. 2005. Harvestmen. Synopses of the British Fauna (New Series), London 4 ( ${ }^{\text {rd }}$ Ed.), 167 pp.

IORIO E., DELFosse E. 2010. Sur les espèces françaises du genre Opilio Herbst, 1798 (Arachnida: Opiliones: Phalangiidae). Bulletin de la Société Linnéenne de Bordeaux 145 (N.S.) 38: 449-460.

KLIMEŠ L. 1995. Nový přírủstek do fauny sekačú Čech. Živa 43: 76-77.

KLIMEŠ L. 1999. Přehlíženi synantropni sekáči (Opiliones): novinky z česko-slovenského pomezi i odjinud. Sbornik Př́rodovědeckeho Klubu Uherské Hradiště 4: 68-71.

KLIMEŠ L., ROUŠAR A. 1998. Remarkable harvestmen from the Czech Republic. Arachnologische Mitteilungen 16: 33-39.

KoMPoscH Ch. 1993. Neue synanthrope Arachniden für Kärnten und die Steiermark (Arachnida: Opiliones, Araneae). Carinthia II 183/103: 803-814.

KomposcH Ch. 2002. Spinnentiere: Spinnen, Weberknechte, Pseudoskorpione, Skorpione (Arachnida: Araneae, Opiliones, Pseudoscorpiones, Scorpiones). In: ESSL F. \& RABITSCH W. (eds) Neobiota in Österreich. Wien, Umweltbundesamt, pp. 250-262.

KOMPOSCH Ch. 2011. Opiliones (Arachnida). In: SCHUSTER R. (Ed.) Checklisten der Fauna Österreichs. Wien (Verlag Österr. Akad. Wiss.), 5: 10-27.

Komposch Ch., GRUBER J. 2004. Die Weberknechte Österreichs (Arachnida, Opiliones). Denisia 12: $485-534$.

LENGYEL G. D. 2010. Contribution to the knowledge of the harverstmen of Hungary (Arachnida: Opiliones). Folia Entomologica Hungarica 71: 5-13.

MARTENS J. 1978. Weberknechte, Opiliones. Die Tierwelt Deutschlands. 64. Jena G. Fischer Verl. 464 pp.

MAS̆ÁN P., MIHÁL I. 2007. New records of Opilio canestrini (Opiliones, Phalangiidae) in Slovakia. Entomofauna Carpathica, 19: 42-43.

Novak T., Slana L., Cervek N., Mlaker M., Zmaher N., Gruber J. 2002. Harvestmen (Opiliones) in human settlements of Slovenia. Acta Entomologica Slovenica 10: 131-154.

RozWALKA R. 2009. Pajęczaki (Arachnida: Araneae, Opiliones) wschodniej części Parku Krajobrazowego Lasy Kozłowieckie. Nowy Pamiętnik Fizjograficzny 6: 71-86.

STAREgGA W. 1963. Kosarze (Opiliones) okolic Warszawy. Fragmenta Faunistica 10: 379-390.

STARĘGA W. 2004. Interessante Weberknechtfunde aus Polen (Arachnida: Opiliones). Arachnologische Mitteilungen 27: $78-88$.

STAUDT A. 2010. Nachweiskarten der Spinnen Deutschlands. Stand: 27.03.2010. Internet:

http:/www.spiderling.de/arages/Verbreitungskarten/Karte1.php?Art=1064

VAN DER WEELE R. 1993. Opilio canestrinii nieuw voor de nederlandse fauna (Opilionida: Phalangiidae). Entomologische Berichten 53: 91.

VANHERCKE L. 1998. Opiliones in Belgium. Internet: http://www.ips.be/ wbm/opilio/home.htm WiJNHOvEN H. 2009. De Nederlandse hooiwagens (Opiliones). Entomologische Tabellen 3, 118 pp.

\section{STRESZCZENIE}

\section{[Inwazyjny kosarz Opilio canestrinii (Thorell, 1876) (Opiliones: Phalangiidae) w Polsce]]}

Opilio canestrinii jest ekspansywnym, inwazyjnym gatunkiem kosarza pochodzacym z Półwyspu Apenińskiego, który w ostatnich dekadach XX wieku rozprzestrzenil się w Europie Środkowej. W pracy przedstawiono nowe informacje o występowaniu tego gatunku w Polsce. $Z$ badań przeprowadzonych w Lublinie wynika, że obecnie $O$. canestrinii jest jednym $\mathrm{z}$ najpospolitszych gatunków kosarzy w miastach. Przedstawione dane sugeruja, że $O$. canestrinii występuje prawdopodobnie w całej Polsce, ale jego występowanie ograniczone jest niemal wyłącznie do dużych lub średnich miast. Pojawienie się wśród synantropijnej fauny nowego przybysza - O. canestrinii - spowodowało zmiany w jej składzie. Zmniejszeniu ulegla zwłaszcza liczebność Opilio parietimus - do niedawna jednego z najczęstszych gatunków kosarzy występujących w biotopach synantropijnych. 